\title{
Article \\ Preparation of Allyl Alcohol Oligomers Using Dipicolinate Oxovanadium(IV) Coordination Compound
}

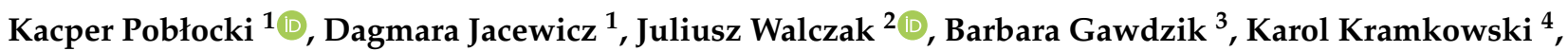 \\ Joanna Drzeżdżon ${ }^{1, *(D)}$ and Paweł Kowalczyk ${ }^{5, *(D)}$
}

1 Department of Environmental Technology, Faculty of Chemistry, University of Gdansk, Wita Stwosza 63, 80-308 Gdansk, Poland; kacperpoblocki@wp.pl (K.P.); dagmara.jacewicz@ug.edu.pl (D.J.)

2 Department of Organic Chemistry, Faculty of Chemistry, Gdansk University of Technology, Narutowicza 11/12, 80-233 Gdansk, Poland; juliusz.walczak@pg.edu.pl

3 Institute of Chemistry, Jan Kochanowski University, Uniwersytecka 7, 25-406 Kielce, Poland; b.gawdzik@ujk.edu.pl

4 Department of Physical Chemistry, Medical University of Bialystok, 15-089 Bialystok, Poland; kkramk@wp.pl

5 Department of Animal Nutrition, The Kielanowski Institute of Animal Physiology and Nutrition, Polish Academy of Sciences, Instytucka 3, 05-110 Jabłonna, Poland

* Correspondence: joanna.drzezdzon@ug.edu.pl (J.D.); p.kowalczyk@ifzz.pl (P.K.)

check for updates

Citation: Pobłocki, K.; Jacewicz, D.; Walczak, J.; Gawdzik, B.;

Kramkowski, K.; Drzeżdżon, J.; Kowalczyk, P. Preparation of Allyl Alcohol Oligomers Using Dipicolinate Oxovanadium(IV) Coordination Compound. Materials 2022, 15, 695. https://doi.org/ $10.3390 / \mathrm{ma} 15030695$

Academic Editor:

Arunas Ramanavicius

Received: 5 December 2021

Accepted: 10 January 2022

Published: 18 January 2022

Publisher's Note: MDPI stays neutral with regard to jurisdictional claims in published maps and institutional affiliations.

Copyright: () 2022 by the authors Licensee MDPI, Basel, Switzerland. This article is an open access article distributed under the terms and conditions of the Creative Commons Attribution (CC BY) license (https:// creativecommons.org/licenses/by/ $4.0 /)$.

\begin{abstract}
Currently, new precatalysts for olefin oligomerization are being sought in the group of vanadium(IV) complexes. Thus, the aim of our research was to examine the catalytic activity of the oxovanadium(IV) dipicolinate complex [VO(dipic) $\left.\left(\mathrm{H}_{2} \mathrm{O}\right)_{2}\right] 2 \mathrm{H}_{2} \mathrm{O}$ (dipic = pyridine-2,6-dicarboxylate anion) in 2-propen-1-ol oligomerization as well as to characterize oligomerization products using matrix-assisted laser desorption/ionization-time-of-flight mass spectrometry (MALDI-TOF-MS), infrared spectroscopy (IR) and nuclear magnetic resonance (NMR). The oligomerization process took place at room temperature, under atmospheric pressure and under nitrogen atmosphere to prevent oxidation of the activator MMAO-12 — the modified methylaluminoxane ( $7 \mathrm{wt} . \%$ ) aluminum in toluene. The last point was to determine the catalytic activity of the complex in the oligomerization reaction of 2-propen-1-ol. The aspect that enriches this work is the proposed mechanism of oligomerization of allyl alcohol based on the literature.
\end{abstract}

Keywords: oligomerization; oxovanadium(IV) complexes; 2-propen-1-ol; catalysis; mechanism of oligomerization; dipicolinate anion

\section{Introduction}

When you hear "polymer", the first thing that comes to mind is plastics. However, increasingly in publications, authors write about polymers or oligomers not only meaning their use in the production of car tires [1,2], packaging [3,4], foil [5,6] or oil [7,8], but also polyolefins used in the production of medical implants [9,10], anti-HIV (human immunodeficiency virus) therapy [11,12], green chemistry [12-14] and Alzheimer's treatment [15,16]. The synthesis of polymers requires special conditions, therefore, catalysts are used which lower the activation energy and speed up the process [17-23]. It has become popular to use metallocenes, e.g., complex compounds containing d-block metals and organic ligands (precatalyst) $[20,21]$. The combination of a precatalyst with an activator, i.e., an organoaluminum compound, e.g., methylaluminoxane (MAO) or a modified methylaluminoxane (MMAO-12, 7\% aluminum in toluene) creates a Ziegler-Natta catalyst [24-27]. The sixth generation of Ziegler-Natta catalysts is the most widespread due to high catalytic activity and attempts to replace MMAO with another activator. The reason is that MMAO changes its structure and composition during storage. Modified methyl aluminoxane, as an activator, oxidizes very quickly when there is oxygen in the reaction system and, therefore, nitrogen is introduced to prevent this. 
The subject of interest of scientists at the beginning of the 20th century was the comparison of the trans spatial structure $\left[\mathrm{VO}(\right.$ dipic $\left.)\left(\mathrm{H}_{2} \mathrm{O}\right)_{2}\right] 2 \mathrm{H}_{2} \mathrm{O}$ (1) to the known compound [VO(dipic)(o-phen)] $3 \mathrm{H}_{2} \mathrm{O}$ (2) by X-ray crystallography and to obtain (2) from (1) by substituting two water molecules with 1,10-phenanthroline. It turned out that the coordination sphere around the oxovanadium(IV) ion was completely transformed during the reaction, which influenced the kinetic aspect [28]. The oxovanadium(IV) dipicolinate complex compound, in its structure, contains dipic (dipicolinate anion), which acts as a tridentate ligand. Thanks to the free electron pair on the nitrogen atom, it can form stable chelates with cations of oxometals from block-d, while showing very different coordination properties. It is used to remove corrosion, decontaminates nuclear reactors, and takes part in biological processes as a carrier of electrons and medical bioimaging [29,30].

Oxovanadium(IV) compounds are used as precatalysts in the polymerization of olefins due to their high catalytic activity and the quality of the products obtained. Vanadium complex compounds are used as catalysts in industrial production of synthetic rubbers, elastomers and polyethylene [31]. However, in our case, special attention was given to the dipicolinate complex of oxovanadium(IV), due to its widely described physicochemical and biological properties such as combating diabetes type I and II [32], cell metabolism [33], antioxidant properties [34], plasmid DNA cleavage, chromosomal aberrations and use in anticancer therapy $[35,36]$. Thorn et al. have reported the application of V-dipic complexes as: [VO(dipic)(i-PrO)], [VO(dipic)(pinme)], [VO(dipic)(dpheol)] and analogs in stoichiometric aerobic oxidation of isopropanol and other alcohols as lignin models [37]. Another example is Gawdzik et al. who reported new oxovanadium(IV) microclusters with 2-phenylpyridine which showed highly activity for the 3-buten-1-ol, 2-chloro-2-propen-1-ol, allyl alcohol, and 2,3-dibromo-2-propen-1-ol oligomerizations [38].

In this publication, for the first time the dipicolinate complex of oxovanadium(IV) is presented as a new precatalyst for an olefin oligomerization. We examined its catalytic properties in the oligomerization of allyl alcohol. The oligomerization reaction products were also analyzed using mass spectrometry techniques such as matrix-assisted laser desorption/ionization time of flight mass spectrometry (MALDI-TOF-MS), infrared spectroscopy (IR) and nuclear magnetic resonance (NMR). The oligomerization process took place at room temperature, under atmospheric pressure and under nitrogen atmosphere, so that the activator, which was MMAO-12, would not oxidize [39]. The aspect that enriches this work is the proposed mechanism of oligomerization of allyl alcohol based on the literature.

\section{Materials and Methods}

\subsection{Materials}

All chemical compounds (vanadyl acetylacetonate, dipicolinic acid, modified methylaluminoxane (7\% aluminum in toluene), 2-propen-1-ol) used in this work were purchased from Sigma-Aldrich (Darmstad, Germany). Their purity was between $98 \%$ and $100 \%$.

\subsection{Dipicolinate Oxovanadium(IV) Complex Synthesis}

Aqueous vanadyl acetylacetonate $\left(\mathrm{VO}(\mathrm{acac})_{2}\right)(2.13 \mathrm{mmol}, 0.57 \mathrm{~g})$ was added to dipicolinic acid ( $\mathrm{H}_{2}$ dipic) $(2.15 \mathrm{mmol}, 0.36 \mathrm{~g})$. Then $50 \mathrm{~cm}^{3}$ of water was added to the mixture. The entire solution was heated at $100{ }^{\circ} \mathrm{C}$ to reflux for $90 \mathrm{~min}$ until the mixture changed color. It took $30 \mathrm{~min}$ to cool down. One month later, the dipicolinate oxovanadium(IV) complex crystallized in the solution in the form of blue crystals. Crystallization was carried out at room temperature. Crystallization lasted so long that it prevented the introduction of impurities that could appear if the process was carried out under conditions of reduced temperature. 


\subsection{Elemental Analysis of the Oxovanadium(IV) Complex Compound with Pyridine-2,6-Dicarboxylate Anion}

Elemental analysis of the complex was performed with the Vario El Cube apparatus. The samples tested by means of elemental analysis were dry and homogeneous with a mass of $2 \mathrm{mg}$.

\subsection{Infrared (IR) Spectra}

The examination of the the oxovanadium(IV) complex compound with pyridine-2,6dicarboxylate anion and the oligomerization product by infrared spectroscopy (IR) was performed in the range from $4000 \mathrm{~cm}^{-1}$ to $600 \mathrm{~cm}^{-1}$ on a KBr pastil. The measurement was carried out on a Bruker IFS 66 spectrometer (Evisa, Tucson, AZ, USA). The IFS 66 apparatus performed infrared spectra in the Fourier transform with a resolution of $0.12 \mathrm{~cm}^{-1}$. DLATGS was a detector in IR measurements.

\subsection{Matrix-Assisted Laser Desorption/Ionization Time of Flight Mass Spectrometry (MALDI-TOF-MS) Spectra}

Molecular weights of the 2 propen-1-ol oligomer chains were determined using MALDI-TOF-MS spectrometer from the Bruker Biflex III company (Billerica, MA, USA). 2,5-Dihydroxybenzoic acid (DHB) was used as a matrix.

\subsection{Nuclear Magnetic Resonance (NMR) Spectra}

Nuclear magnetic resonance spectra of oligomerization products were recorded with a Bruker Avance III 500 spectrometer (Billerica, MA, USA). The measurement was carried out at $25^{\circ} \mathrm{C}$. The measured frequency was $126 \mathrm{MHz}$ for ${ }^{13} \mathrm{C}$ NMR and $500 \mathrm{MHz}$ for ${ }^{1} \mathrm{H}$ NMR. The solvent that was used was deuterated 1,1,2,2-tetrachloroethane.

\subsection{The Oligomerization Process}

The oligomerization process was carried out in a glass flask closed with a stopper (Figure 1). First, the precatalyst which was $\left[\mathrm{VO}\left(\right.\right.$ dipic) $\left(\mathrm{H}_{2} \mathrm{O}_{2}\right] 2 \mathrm{H}_{2} \mathrm{O}$ (Figure 2$)(3 \mu \mathrm{mol}$, $0.912 \mathrm{mg}$ ) was dissolved in $1 \mathrm{~mL}$ of toluene and $1 \mathrm{~mL}$ of anhydrous DMSO (anhydrous dimethyl sulfoxide). The solution was then mixed with a magnetic stirrer. In the next step, the following reagents were added: $3 \mathrm{~mL}$ of MMAO- 12 (modified methylaluminoxane, $7 \%$ aluminium in toluene) and $3 \mathrm{~mL}$ of 2-propen-1-ol. The whole oligomerization process was undertaken at ambient pressure $(1013 \mathrm{hPa})$, at room temperature and in nitrogen air. After 90 min of oligomerization, a white gel was obtained and then it was washed with a mixture of $1 \mathrm{M}$ hydrochloric acid and $1 \mathrm{M}$ methanol in a 1:1 molar ratio.

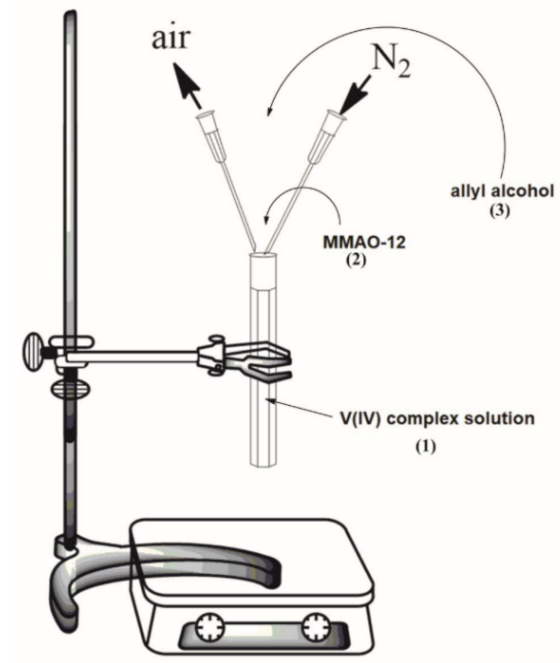

Figure 1. A process flow diagram for the oligomerization system. 


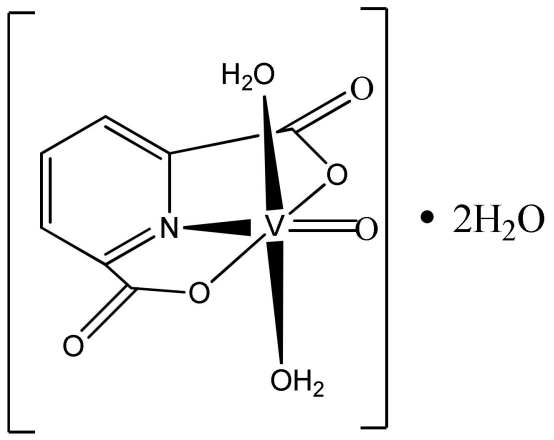

Figure 2. Chemical structure of $\left[\mathrm{VO}(\right.$ dipic $\left.)\left(\mathrm{H}_{2} \mathrm{O}\right)_{2}\right] 2 \mathrm{H}_{2} \mathrm{O}$.

\section{Results and Discussion}

The structure of the complex is well known and described in the literature [40]. Table 1 shows the percentages of elements obtained by exploiting the elemental analysis (AE) technique and theoretical calculations.

Table 1. Results of elemental analysis of the synthesized complex $\left[\mathrm{VO}(\right.$ dipic $\left.)\left(\mathrm{H}_{2} \mathrm{O}\right)_{2}\right] \bullet 2 \mathrm{H}_{2} \mathrm{O}(\mathrm{AE}$ means experimental data, $\mathrm{T}$ denotes theoretical data).

\begin{tabular}{|c|c|c|c|c|c|c|}
\hline \multirow{3}{*}{ Complex Compound } & \multicolumn{6}{|c|}{ Percentage [\%] } \\
\hline & \multicolumn{2}{|c|}{$\% \mathrm{C}$} & \multicolumn{2}{|c|}{$\% \mathbf{H}$} & \multicolumn{2}{|c|}{$\% \mathbf{N}$} \\
\hline & $\mathrm{AE}$ & $\mathbf{T}$ & $\mathrm{AE}$ & $\mathrm{T}$ & $\mathrm{AE}$ & $\mathbf{T}$ \\
\hline$\left[\mathrm{VO}\right.$ (dipic) $\left.\left(\mathrm{H}_{2} \mathrm{O}\right)_{2}\right] 2 \mathrm{H}_{2} \mathrm{O}$ & 27.64 & 27.46 & 3.60 & 4.25 & 4.70 & 4.58 \\
\hline
\end{tabular}

Theoretical data have been calculated according to the following procedure:

Mass of $\left[\mathrm{VO}\left(\right.\right.$ dipic) $\left.\left(\mathrm{H}_{2} \mathrm{O}\right)_{2}\right] 2 \mathrm{H}_{2} \mathrm{O}=305.9 \mathrm{~g} / \mathrm{mol} ; \% \mathrm{C}=84 / 305.9 \times 100 \%=27.46 \%$; $\% \mathrm{H}=13 / 305.9 \times 100 \%=4.25 \% ; \% \mathrm{~N}=14 / 305.9 \times 100 \%=4.58 \%$.

In order to confirm the structure of the synthesized crystal of complex compound, we described the IR spectrum of the dipicolinate oxovanadium(IV) complex (Figure 3) [41].

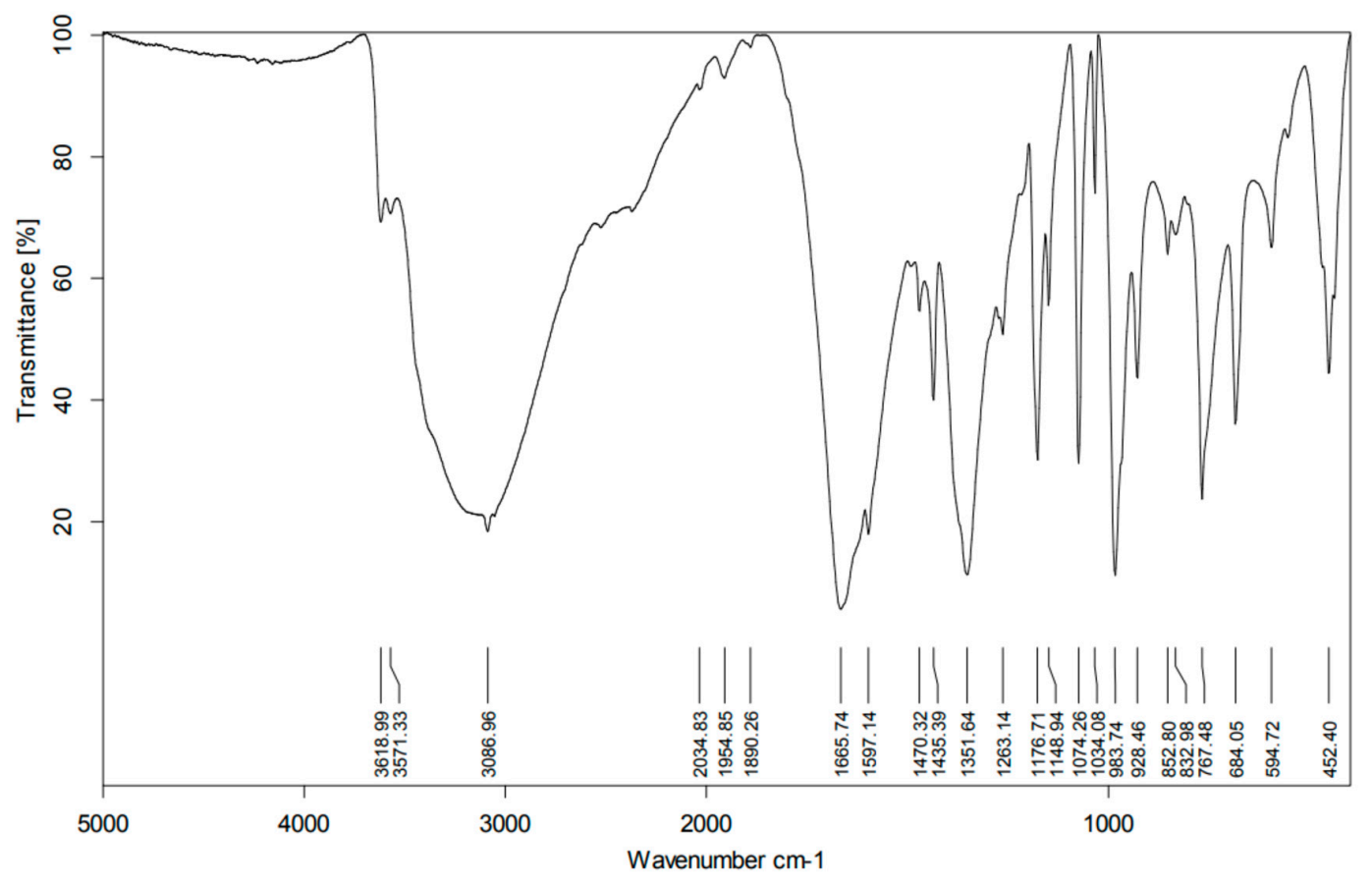

Figure 3. Infrared (IR) spectrum of [VO(dipic) $\left.\left(\mathrm{H}_{2} \mathrm{O}\right)_{2}\right] 2 \mathrm{H}_{2} \mathrm{O}$ [41]. 
The characterization results presented in Tables 1 and 2 and their validation with theoretical calculations and literature data indicate that the vanadium complex synthesis was correct [41,42]. The synthesized complex was used for 2-propen-1-ol oligomerization. Analysis of the IR spectrum (Figure 4) of the product of 2-propen-1-ol oligomerization is presented in Table 3. The absorption of infrared radiation is accompanied by changes in the vibrational energy of the molecules. Since this energy is quantified, only radiation with certain energies, specific to the functional groups performing the vibrations, is absorbed. This makes it possible to determine which functional groups are present in the analyzed sample. The condition for absorption of radiation is the change in the dipole moment of the molecule during the process. The results of the IR studies showed that the end product of the oligomerization contained a double bond and a hydroxyl group. The IR studies confirmed the structure of the oligomerization products [43,44].

Table 2. Characteristic IR spectrum absorption bands of [VO(dipic $\left.)\left(\mathrm{H}_{2} \mathrm{O}\right)_{2}\right] 2 \mathrm{H}_{2} \mathrm{O}[41,42]$.

\begin{tabular}{cc}
\hline Wavenumber $\left[\mathrm{cm}^{-\mathbf{1}}\right]$ & Type of Vibration with Function Group \\
\hline 3571 & $v(\mathrm{OH})$ \\
1665 & $v(\mathrm{COO})$ of dipic \\
1352 & $v(\mathrm{COO})$ of dipic \\
983 & $\mathrm{~V}=\mathrm{O}$ stretching frequency \\
452 & stretching vibration of the V-N \\
\hline
\end{tabular}

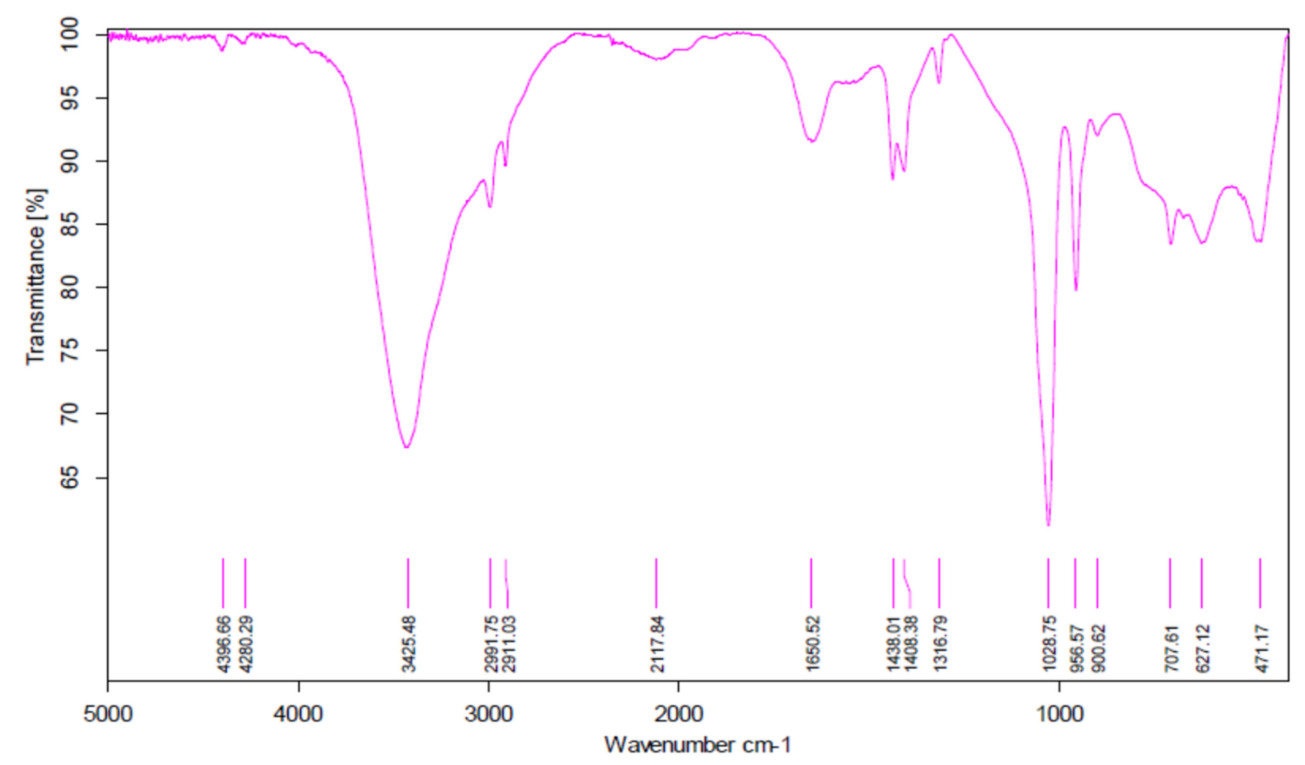

Figure 4. IR spectrum of the 2-propen-1-ol oligomerization product.

Table 3. Characteristic IR spectrum absorption bands for the 2-propen-1-ol oligomerization product $[43,44]$.

\begin{tabular}{ccc}
\hline Wavenumber $\left[\mathrm{cm}^{-\mathbf{1}}\right]$ & Type of Vibration & Function Group \\
\hline 3425 & stretching vibrations & $-\mathrm{OH}$ \\
2992 & stretching vibrations & $-\mathrm{CH}$ \\
1651 & stretching vibrations & $\mathrm{C}=\mathrm{C}$ \\
1438 & bending vibrations & $-\mathrm{CH}_{2}$ \\
\hline
\end{tabular}

Using the MALDI-TOF-MS method, we characterized certain peaks, thus allowing the identification of the number of units present in the oligomer chains using [VO(dipic $)\left(\mathrm{H}_{2} \mathrm{O}\right)_{2}$ ] $2 \mathrm{H}_{2} \mathrm{O}$ as a precatalyst (Figure 5). 


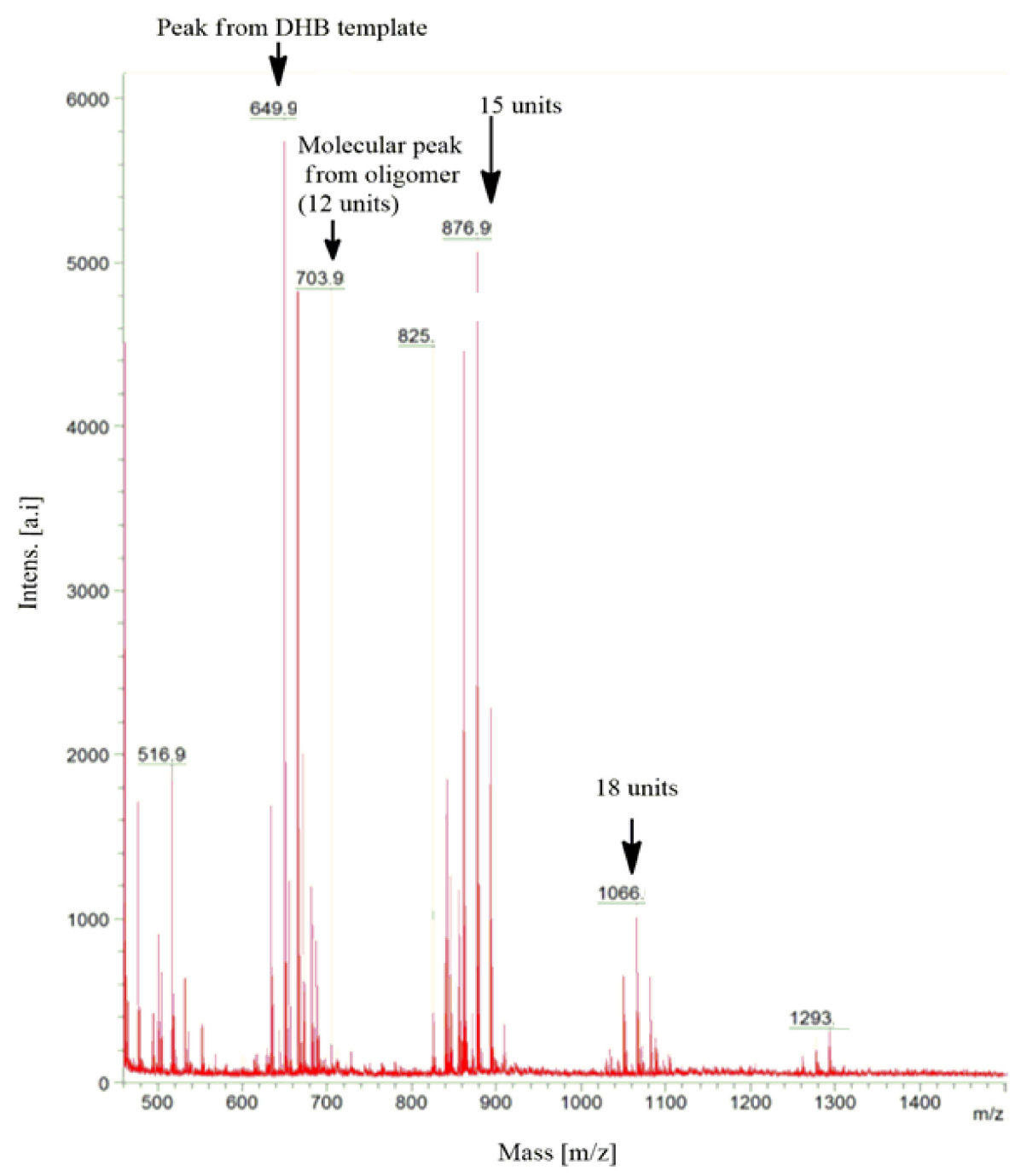

Figure 5. The matrix-assisted laser desorption/ionization time of flight mass spectrometry (MALDITOF-MS) spectrum of the products of the oligomerization process.

The presence of oligomer chains of a specific length was confirmed by using mass spectrometry. The appropriate units were assigned to the peaks in the spectra formed in the process of 2-propen-1-ol oligomerization catalyzed by $\left[\mathrm{VO}(\right.$ dipic $\left.)\left(\mathrm{H}_{2} \mathrm{O}\right)_{2}\right] 2 \mathrm{H}_{2} \mathrm{O}$. The $649.9 \mathrm{~m} / \mathrm{z}$ peak was derived from 2,5-dihydroxybenzoic acid-the matrix and molecular peak were identified with a mass/charge ratio of $703.9 \mathrm{~m} / \mathrm{z}$ that contained 2-propen-1-ol 12 units. The next peaks at $m / z=876.9$ (15 units), $m / z=1066$ (18 units) were observed in the attached mass spectrum. This was a confirmation that in the obtained 2-propen-1-ol mixture, the oligomers contained chains consisting of 12,15 and 18 allyl alcohol units.

Analysis of 2-propen-1-ol oligomerization products was conducted using nuclear magnetic resonance spectroscopic techniques. The ${ }^{1} \mathrm{H}$ NMR spectrum is shown in Figure 6 and the ${ }^{13} \mathrm{C}$ NMR spectrum is shown in Figure 7.

In order to illustrate the structure of 2-propen-1-ol oligomers more precisely, the Tables 4 and 5 based on the ${ }^{1} \mathrm{H}$ NMR and ${ }^{13} \mathrm{C}$ NMR spectra were prepared. The peak values corresponding to specific carbon and hydrogen atoms depending on the type of spectrum have been highlighted. NMR spectroscopy is based on the observation of transitions between magnetic energy levels of the ${ }^{1} \mathrm{H}$ hydrogen isotope in the case of ${ }^{1} \mathrm{H}$ NMR. A lot of information about the structure of the molecule under study can be obtained from the NMR spectra. The number of signals provides information about the number of protons lying in the same environment. The intensity of the signals is proportional to the number of protons associated with this signal. On the other hand, the values of chemical shifts 
of signals in the spectrum depend on the environment in which the protons are located. The larger the peak, the stronger the coupling of the interaction between adjacent electron nuclei, the so-called spin-spin couplings. NMR and IR test results confirm the structure of the oligomers obtained consisting of linked units of allyl alcohol.

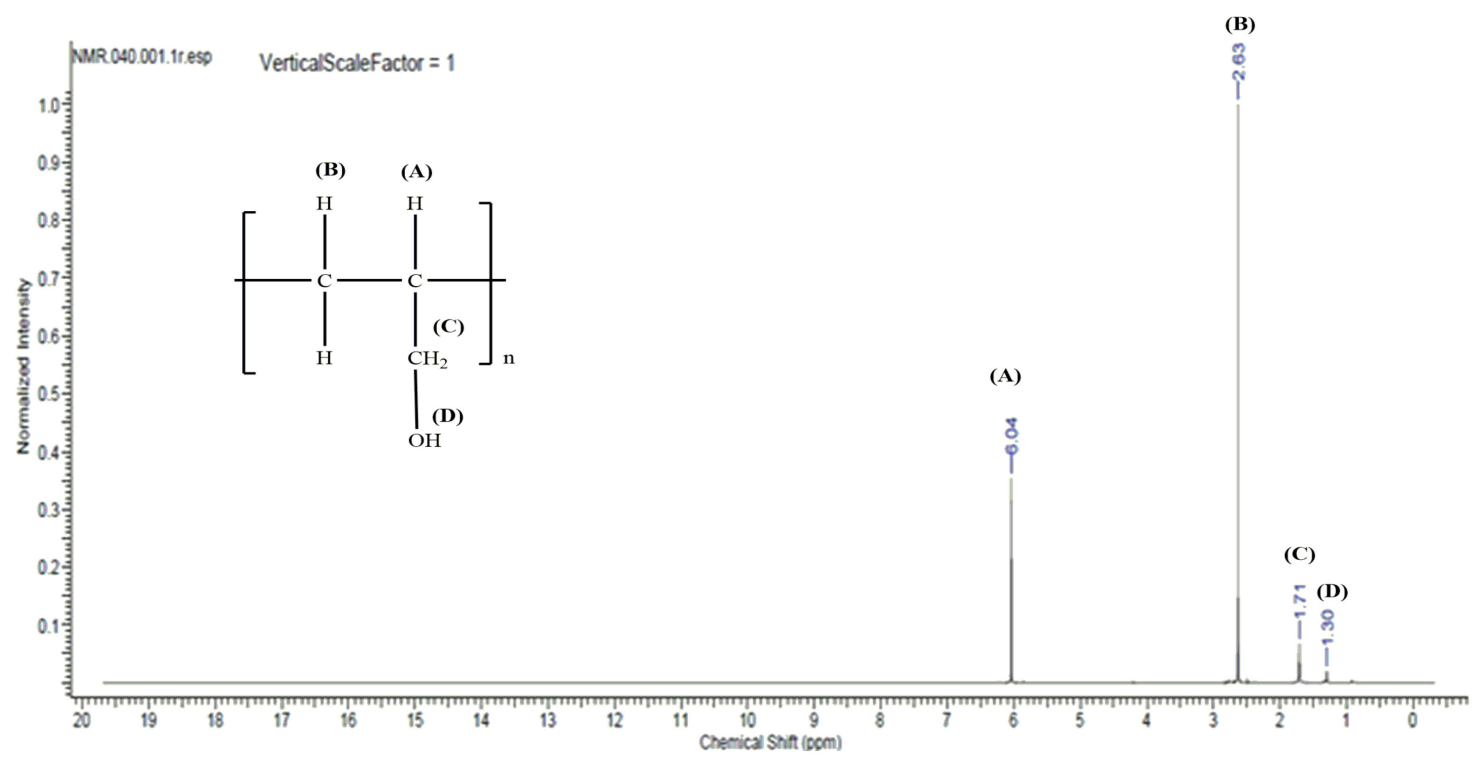

Figure 6. ${ }^{1} \mathrm{H}$ nuclear magnetic resonance (NMR) spectrum for 2-propen-1-ol oligomerization products obtained with the application of $\left[\mathrm{VO}(\right.$ dipic $\left.)\left(\mathrm{H}_{2} \mathrm{O}\right)_{2}\right] \bullet 2 \mathrm{H}_{2} \mathrm{O}+\mathrm{MMAO}-12$.

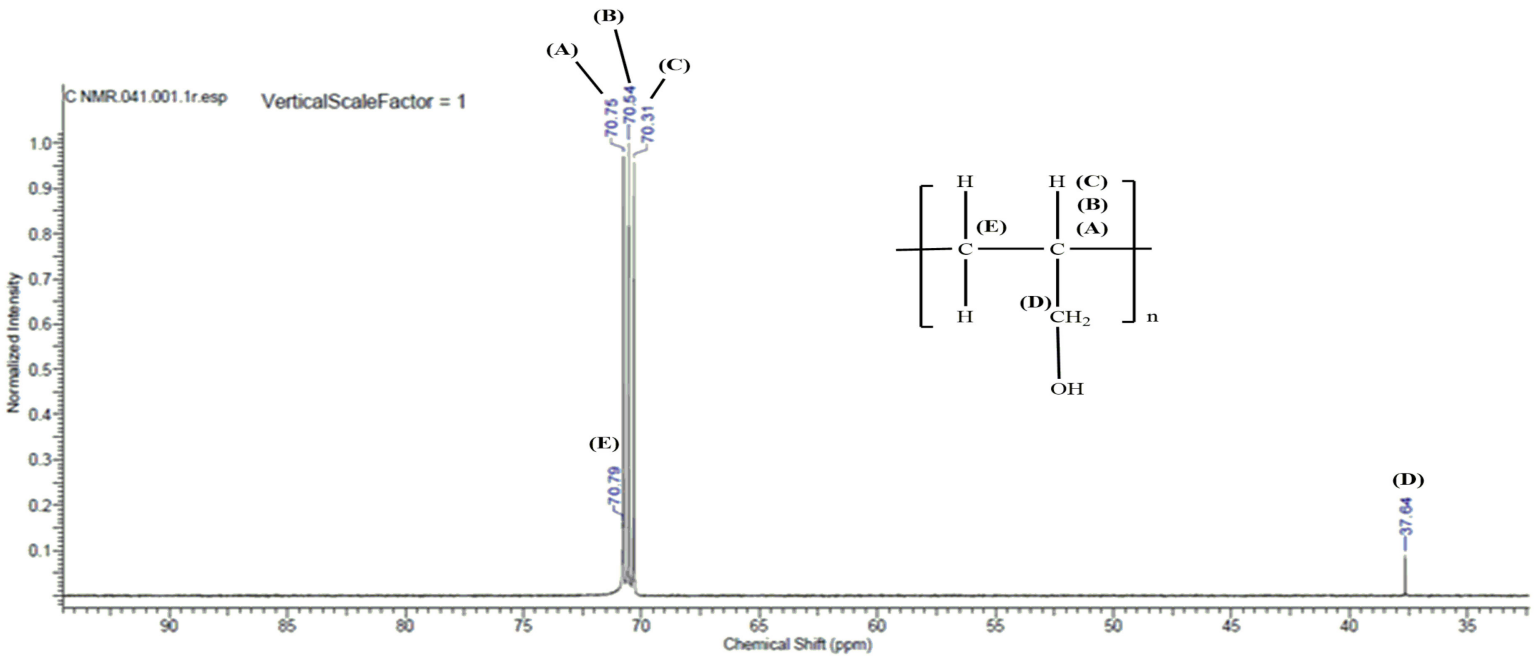

Figure 7. ${ }^{13} \mathrm{C}$ NMR spectrum for 2-propen-1-ol oligomerization products obtained with the application of $\left[\mathrm{VO}\right.$ (dipic) $\left.\left(\mathrm{H}_{2} \mathrm{O}\right)_{2}\right] 2 \mathrm{H}_{2} \mathrm{O}+\mathrm{MMAO}-12$.

Table 4. Peak values and the corresponding hydrogen atoms derived from the $1 \mathrm{H}$ NMR spectrum for the products of 2-propen-1-ol oligomerization catalyzed by [VO(dipic)(H2O)2] • $2 \mathrm{H} 2 \mathrm{O}+\mathrm{MMAO}-12$.

\begin{tabular}{cc}
\hline Peak Value & Assigned Hydrogen Atoms \\
\hline 6.04 & $\mathrm{CH}_{2}=\mathrm{CH}$ - (oligomer) \\
2.63 & $\mathrm{CH}_{2}=\mathrm{CH}$ - (monomer) \\
1.71 & $\mathrm{HO}^{-} \mathrm{CH}_{2}$ - (oligomer) \\
1.30 & $-\mathrm{OH}$ (oligomer) \\
\hline
\end{tabular}


Table 5. Peak values and the corresponding hydrogen atoms derived from the ${ }^{13} \mathrm{C}$ NMR spectrum for the products of 2-propen-1-ol oligomerization catalyzed by [VO(dipic) $\left.\left(\mathrm{H}_{2} \mathrm{O}\right)_{2}\right] 2 \mathrm{H}_{2} \mathrm{O}+\mathrm{MMAO}-12$.

\begin{tabular}{cc}
\hline Peak Value & Assigned Carbons Atoms \\
\hline 70.79 & $\mathrm{HO}-\mathrm{CH}_{2}-\mathrm{CH}-\mathrm{CH}_{2}$ - (oligomer) \\
\hline $70.76-70.31$ & $\mathrm{HO}-\mathrm{CH}_{2}-\mathrm{CH}-\mathrm{CH}_{2}$ ( oligomer) \\
\hline 37.64 & $-\mathrm{CH}_{2}-\mathrm{OH}$ (oligomer) \\
\hline
\end{tabular}

The catalytic activity $(\mathrm{Ca})$ for the $\left[\mathrm{VO}(\right.$ dipic $\left.)\left(\mathrm{H}_{2} \mathrm{O}\right)_{2}\right] \bullet 2 \mathrm{H}_{2} \mathrm{O}$ complex compound can be calculated from the formula:

$$
\mathrm{C}_{\mathrm{a}}=\frac{\mathrm{m}}{n \cdot p \cdot t}=191.53 \frac{\mathrm{g}}{\mathrm{mmol} \cdot \mathrm{bar} \cdot \mathrm{h}}
$$

where: $\mathrm{m}$-mass of obtained oligomer [g]; $n$-number of mmoles of $\mathrm{V}^{4+}[\mathrm{mmol}] ; p-$ pressure [bar]; $t$-oligomerization time [h].

The literature values were compared in Table 6 with the result of the calculations to find out how effective the precatalyst was. The number of mmole of $\mathrm{V}^{4+}$ used to calculate the catalytic activity $(\mathrm{Ca})$ was calculated theoretically. In these calculations there is the lack of mass balance calculation, thus the calculation has uncertainties that can lead to misleading comparisons with the data presented in Table 6.

Table 6. Catalyst efficiency classification based on their catalytic activity [45].

\begin{tabular}{cc}
\hline Catalyst Efficiency & Catalytic Activity $\mathbf{~} \mathbf{g} \cdot \mathbf{m m o l}^{\mathbf{- 1}} \cdot \mathbf{b a r}^{\mathbf{- 1}} \cdot \mathbf{h}^{\mathbf{- 1}} \mathbf{]}$ \\
\hline Very low & $<1$ \\
Low & $1-10$ \\
Moderate & $10-100$ \\
High & $100-1000$ \\
Very high & $>1000$ \\
\hline
\end{tabular}

Comparing the calculated results with the literature values, we concluded that the precatalyst [VO(dipic) $\left.\left(\mathrm{H}_{2} \mathrm{O}\right)_{2}\right] 2 \mathrm{H}_{2} \mathrm{O}$ belonged to the group of catalysts with high catalytic activity. The highest catalytic activity in the research to date had been noticed with olefins containing chlorine in their structure, for example 2-chloro-2-propen-1-ol. Thus, by achieving high purity, process efficiency could be increased. The use of ligands also played an important role. Too extensive chains of organic clusters caused steric barrier and thus low selectivity.

\section{The Proposed Mechanism of the Oligomerization Reaction of 2-Propen-1-ol Catalyzed by [VO(dipic) $\left.\left(\mathrm{H}_{2} \mathrm{O}\right)_{2}\right] 2 \mathrm{H}_{2} \mathrm{O}+\mathrm{MMAO}-12$}

The mechanism of the oligomerization reaction of 2-propen-1-ol catalyzed by [VO(dipic) $\left.\left(\mathrm{H}_{2} \mathrm{O}\right)_{2}\right] 2 \mathrm{H}_{2} \mathrm{O}$, with the participation of an activator (MMAO-12), followed the mechanism of coordination polymerization based on the literature [46-49] (Figure 8). The approach of allyl alcohol to the center of oxovanadium(IV) with the participation of MMAO-12 caused the formation of the $\pi$ complex between the alcohol's double bond and the active center (Step 1). In the next step, coupling took place between the terminal carbon atom and the active center of oxovanadium(IV), at the expense of the water molecule from the precatalyst, which migrated to the activator. The resulting electrophilic center-carbocation-then underwent a nucleophilic attack by the $\pi$ bond of allylic alcohol and thus propagated the alkyl chain (Step 2). In the elimination stage, the obtained oligomer separated from the dipicolinate complex of oxovanadium(IV) and modified methylaluminoxane, through the migration of a water molecule from MMAO-12 to the active center (Step 3). Washing the oligomer with a mixture of diluted hydrochloric acid and methanol removed residual catalyst and activator. The washing step was important because the activator also reverted 
to its native form and the cleaved oligomer, due to the momentary and opposite polarity on the carbon atoms, could produce a polymeric structure written according to the standard that could restore the stable structure of the catalyst under hydrolytic conditions. Another fact confirmed the correctness of the proposed termination step, involving the experiment, in which we added water to the reaction mixture after the oligomerization process. As a result, we observed a free activator molecule precipitating out from a solution, suggesting that it was not bound to the catalyst any more. It is worth emphasizing that this mechanism was also based on the fact that the greater the weight of a polymer, the better the properties as a leaving group it constituted, thus making this reaction self-limiting [46-49].

Step 1

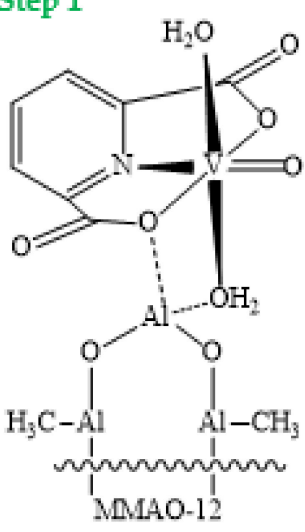

Step 2<smiles>C=CCO</smiles>

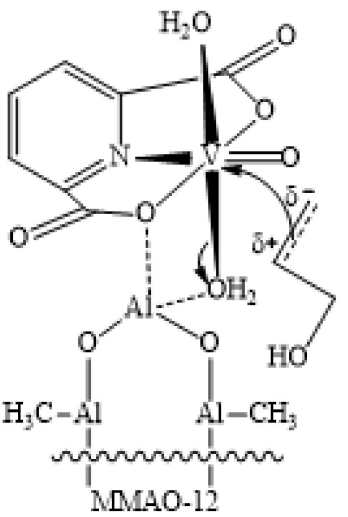

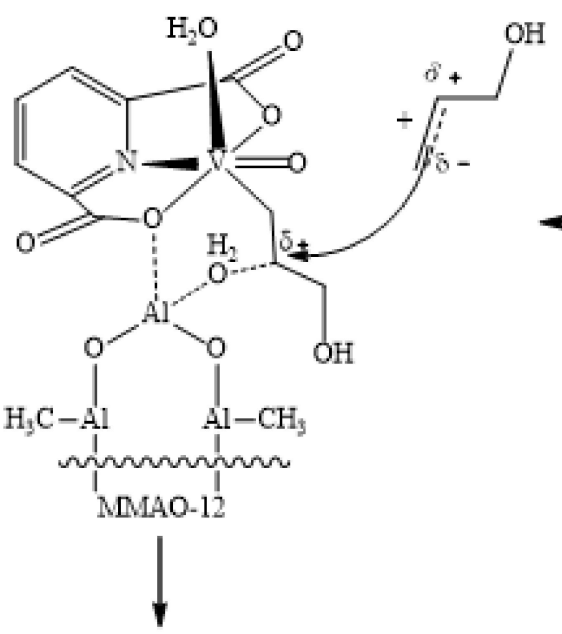<smiles>C=CC1CC1</smiles>

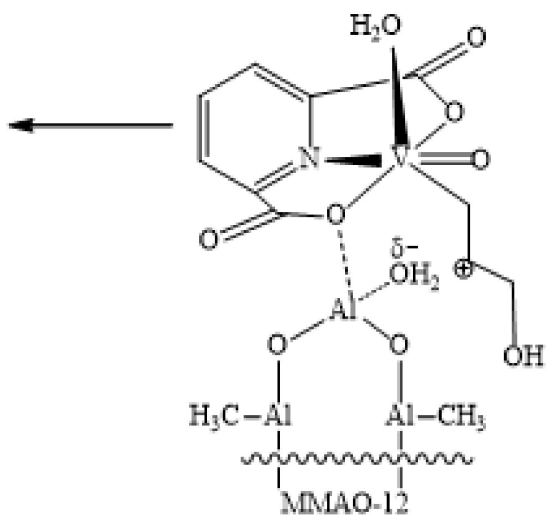

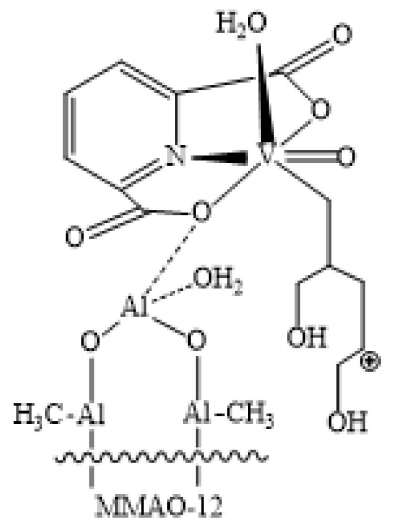

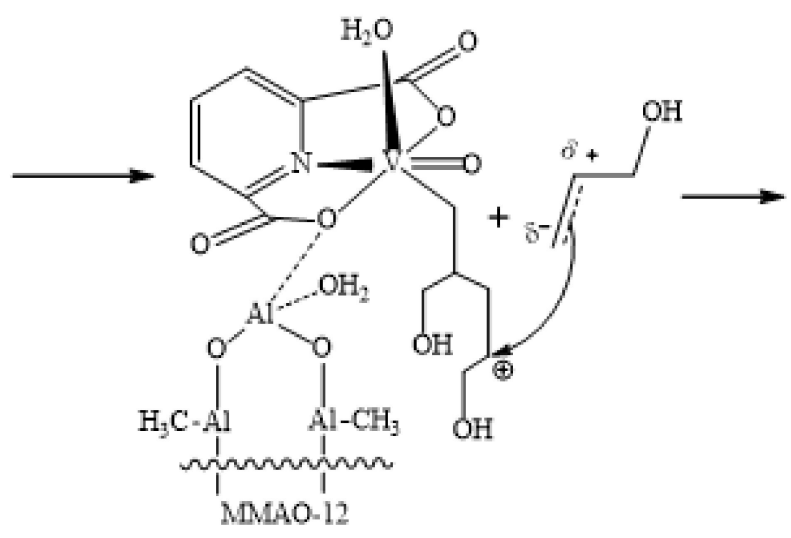

Figure 8. Cont. 


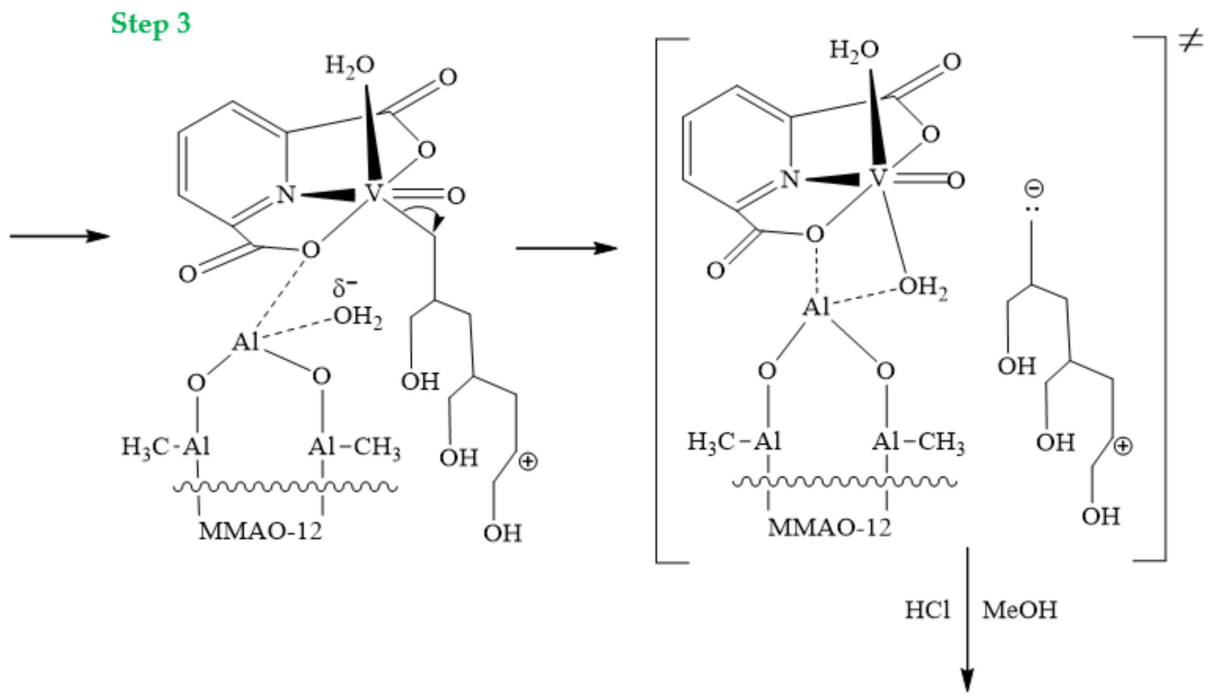

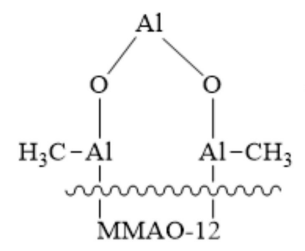<smiles>COc1cccc2c1OC(=O)[N+]2(C(=O)O)C(=O)O</smiles><smiles>CC(CC(O)CCO)CC(C)(C)CC(CO)C(C)C</smiles>

Figure 8. The proposed mechanism of 2-propen-1-ol oligomerization with the application of [VO(dipic) $\left.\left(\mathrm{H}_{2} \mathrm{O}\right)_{2}\right] 2 \mathrm{H}_{2} \mathrm{O}+\mathrm{MMAO}-12$. Step 1 (Initiation), Step 2 (Propagation), Step 3 (Termination) [46-49].

\section{Conclusions}

The oxovanadium(IV) dipicolinate complex compound is an effective precatalyst for the oligomerization process of 2-propen-1-ol carried out at room temperature, under nitrogen atmosphere and at atmospheric pressure. Several methods-IR, MALDI-TOFMS, ${ }^{1} \mathrm{H}$ and ${ }^{13} \mathrm{C}$ NMR - confirmed that the obtained mixture of 2-propen-1-ol oligomers contained 12, 15 and 18 units of allyl alcohol. It can be stated that the dipicolinate complex of oxovanadium(IV) was a highly active precatalyst with $191.53 \mathrm{~g} \mathrm{mmol}^{-1} \mathrm{bar}^{-1} \mathrm{~h}^{-1}$ catalytic activity value. Our results showed that further examinations towards the potential olefin oligomerization precatalysts need to be undertaken, especially those derived from the dipocolinate oxovanadium(IV) complex.

Author Contributions: K.P.: Investigation, Formal analysis, Mechanism, Writing-Original Draft. D.J.: Conceptualization, Formal analysis, Methodology, Writing-Original Draft, Writing-Review and Editing, Project administration. J.W.: Mechanism, Writing-Review and Editing. B.G., Investigation, Methodology, Formal analysis, K.K.-funding acquisition, J.D.: Conceptualization, Investigation, Methodology, Formal analysis, Writing-Original Draft, Writing-Review and Editing. P.K. WritingReview and Editing. All authors have read and agreed to the published version of the manuscript.

Funding: This research was funded by Jan Kochanowski University, grant number SUPS.RN.21.046. This work was supported by a grant from the Medical University of Białystok SUB/2DN/21/001/2201 and SUB/2/DN/20/003/2201 and by the National Science Center, Poland, project OPUS No. 2019/33/B/ST4/01118.

Institutional Review Board Statement: Not applicable.

Informed Consent Statement: Not applicable. 
Conflicts of Interest: The authors declare no conflict of interest.

\section{References}

1. Verma, A.; Budiyal, L.; Sanjay, M.R.; Siengchin, S. Processing and characterization analysis of pyrolyzed oil rubber (from waste tires)-epoxy polymer blend composite for lightweight structures and coatings applications. Polym. Eng. Sci. 2019, 59, $2041-2051$. [CrossRef]

2. Baricevic, A.; Pezer, A.; Rukavina, M.J.; Serdar, M.; Stirmer, N. Effect of polymer fibers recycled from waste tires on properties of wet-sprayed concrete. Constr. Build. Mater. 2018, 176, 135-144. [CrossRef]

3. Rezić, I.; Haramina, T.; Rezić, T. Metal nanoparticles and carbon nanotubes-Perfect antimicrobial nano-fillers in polymer-based food packaging materials. In Food Packaging: Nanotechnology in the Agri-Food Industry; Grumezescu, A.M., Ed.; Academic Press: Cambridge, MA, USA, 2017; Volume 7, pp. 497-532.

4. Youssef, A.M.; El-Sayed, S.M. Bionanocomposites materials for food packaging applications: Concepts and future outlook. Carbohydr. Polym. 2018, 193, 19-27. [CrossRef] [PubMed]

5. Rößler, F.; Günther, K.; Lasagni, A.F. In-volume structuring of a bilayered polymer foil using direct laser interference patterning. Appl. Surf. 2018, 440, 1166-1171. [CrossRef]

6. Passlack, U.; Simon, N.; Buche, V.; Harendt, C.; Stieglitz, T.; Burghartz, J.N. Investigation of long-term stability of hybrid systemsin-foil (HySiF) for biomedical applications. In Proceedings of the 2020 IEEE 8th Electronics System-Integration Technology Conference (ESTC), Tønsberg, Norway, 15-18 September 2020; pp. 1-6.

7. Firozjaii, A.M.; Saghafi, H.R. Review on chemical enhanced oil recovery using polymer flooding: Fundamentals, experimental and numerical simulation. Petroleum 2020, 6, 115-122. [CrossRef]

8. Zhou, W.; Xin, C.; Chen, S.; Yu, Q.; Wang, K. Polymer-enhanced foam flooding for improving heavy oil recovery in thin reservoirs. Energy Fuels 2020, 34, 4116-4128. [CrossRef]

9. Da Silva, D.; Kaduri, M.; Poley, M.; Adir, O.; Krinsky, N.; Shainsky-Roitman, J.; Schroeder, A. Biocompatibility, biodegradation and excretion of polylactic acid (PLA) in medical implants and theranostic systems. Chem. Eng. J. 2018, 340, 9-14. [CrossRef]

10. Al-Obaidi, A.; Kunke, A.; Kräusel, V. Hot single-point incremental forming of glass-fiber-reinforced polymer (PA6GF47) supported by hot air. J. Manuf. Process 2019, 43, 17-25. [CrossRef]

11. Xu, J.; Merlier, F.; Avalle, B.; Vieillard, V.; Debré, P.; Haupt, K.; Tse Sum Bui, B. Molecularly imprinted polymer nanoparticles as potential synthetic antibodies for immunoprotection against HIV. ACS Appl. Mater. Interfaces 2019, 11, 9824-9831. [CrossRef] [PubMed]

12. Notario-Pérez, F.; Cazorla-Luna, R.; Martín-Illana, A.; Ruiz-Caro, R.; Tamayo, A.; Rubio, J.; Veiga, M.D. Optimization of tenofovir release from mucoadhesive vaginal tablets by polymer combination to prevent sexual transmission of HIV. Carbohydr. Polym. 2018, 179, 305-316. [CrossRef]

13. Worthington, M.J.H.; Kucera, R.L.; Chalker, J.M. Green chemistry and polymers made from sulfur. Green Chem. 2017, 19, 2748-2761. [CrossRef]

14. Jahangirian, H.; Lemraski, E.G.; Webster, T.J.; Rafiee-Moghaddam, R.; Abdollahi, Y. A review of drug delivery systems based on nanotechnology and green chemistry: Green nanomedicine. Int. J. Nanomed. 2017, 12, 2957-2978. [CrossRef]

15. Sahoo, B.R.; Genjo, T.; Bekier, M., II; Cox, S.J.; Stoddard, A.K.; Ivanova, M.; Yasuhara, K.; Fierke, C.A.; Wang, Y.; Ramamoorthy, A. Alzheimer's amyloid-beta intermediates generated using polymer-nanodiscs. Commun. Chem. 2018, 54, 12883-12886. [CrossRef]

16. Carradori, D.; Balducci, C.; Re, F.; Brambilla, D.; Le Droumaguet, B.; Flores, O.; Gaudin, A.; Mura, S.; Forloni, G.; OrdoñezGutierrez, L.; et al. Antibody-functionalized polymer nanoparticle leading to memory recovery in Alzheimer's disease-like transgenic mouse model. Nanomedicine 2018, 14, 609-618. [CrossRef] [PubMed]

17. Tang, Z.-E.; Lim, S.; Pang, Y.-L.; Ong, H.-C.; Lee, K.-T. Synthesis of biomass as heterogeneous catalyst for application in biodiesel production: State of the art and fundamental review. Renew. Sustain. Energ. Rev. 2018, 92, 235-253. [CrossRef]

18. Putra, M.D.; Irawan, C.; Udiantoro; Ristianingsih, Y.; Nata, I.F. A cleaner process for biodiesel production from waste cooking oil using waste materials as a heterogeneous catalyst and its kinetic study. J. Clean. Prod. 2018, 195, 1249-1258. [CrossRef]

19. Shen, Z.; Cao, M.; Zhang, Z.; Pu, J.; Zhong, C.; Li, J.; Ma, H.; Li, F.; Zhu, J.; Pan, F.; et al. Efficient Ni2Co4P3 nanowires catalysts enhance ultrahigh-loading lithium-sulfur conversion in a microreactor-like battery. Adv. Funct. Mater. 2020, 30, 1906661. [CrossRef]

20. Gawdzik, B.; Kamizela, A.; Szyszkowska, A. Lactones with a fragrance properties. Chemist 2015, 69, 346-349.

21. Kamizela, A.; Gawdzik, B.; Urbaniak, M.; Lechowicz, Ł.; Białońska, A.; Gonciarz, W.; Chmiela, M. Synthesis, characterization, cytotoxicity, and antibacterial properties of trans- $\gamma$-Halo- $\delta$-lactones. ChemistryOpen 2018, 7, 543-550. [CrossRef]

22. Drzeżdżon, J.; Piotrowska-Kirschling, A.; Malinowski, J.; Kloska, A.; Gawdzik, B.; Chmurzyński, L.; Jacewicz, D. Antimicrobial, cytotoxic, and antioxidant activities and physicochemical characteristics of chromium(III) complexes with picolinate, dipicolinate, oxalate, 2, 2'-bipyridine, and 4, 4'-dimethoxy-2, 2'-bipyridine as ligands in aqueous solutions. J. Mol. Liq. 2019, 282, $441-447$. [CrossRef]

23. Gawdzik, B.; Iwanek, W. Synthesis, structure, and stereochemistry of the bora derivatives of 1-[(2-hydroxy-1-naphthyl) methyl] proline. Tetrahedron Asymmetry 2005, 16, 2019-2023. [CrossRef]

24. Drzeżdżon, J.; Sikorski, A.; Chmurzyński, L.; Jacewicz, D. New type of highly active chromium(III) catalysts containing both organic cations and anions designed for polymerization of beta-olefin derivatives. Sci.Rep. 2018, 8, 2315. [CrossRef] [PubMed] 
25. Gibson, V.C.; Spitzmesser, S.K. Advances in non-metallocene olefin polymerization catalysis. Chem. Rev. 2003, 103, 283-316. [CrossRef]

26. Vitorino, M.J.; Devic, T.; Tromp, M.; Férey, G.; Visseaux, M. Lanthanide Metal-Organic Frameworks as Ziegler-Natta Catalysts for the Selective Polymerization of Isoprene. Chem. Phys. 2009, 210, 1923-1932. [CrossRef]

27. Kayda, A.S.; Rumyantsev, A.V.; Zubkevich, S.V.; Zhizhko, P.A.; Takazova, R.U.; Tuskaev, V.A.; Gagieva, S.C.; Buzin, M.I.; Shatokhin, S.S.; Nikiforova, G.G.; et al. Vanadium(V) imido chlorides and n-propoxides-Towards a rational design of vanadium imido precatalysts for ethylene polymerization. J. Organomet. Chem. 2021, 934, 121665. [CrossRef]

28. Chatterjee, M.; Ghosh, S.; Nandi, A.K. X-ray crystal structure of [VO(DPA)(H2O) 2] 2H2O (DPA = Dipicolinate dianion). Transit. Met. Chem. 1999, 24, 183-185. [CrossRef]

29. Rončević, S.; Nemet, I.; Ferri, T.Z.; Matković-Čalogović, D. Characterization of nZVI nanoparticles functionalized by EDTA and dipicolinic acid: A comparative study of metal ion removal from aqueous solutions. RSC Adv. 2019, 9, 31043-31051. [CrossRef]

30. Sengupta, P.; Ghosh, S.; Mak, T.C. A new route for the synthesis of bis(pyridine dicarboxylato) bis(triphenylphosphine) complexes of ruthenium(II) and X-ray structural characterisation of the biologically active trans-[Ru(PPh3)2(L1H)2](L1H2= pyridine 2, 3-dicarboxylic acid). Polyhedron 2001, 20, 975-980. [CrossRef]

31. Wu, J.-Q.; Li, Y.-S. Well-defined vanadium complexes as the catalysts for olefin polymerization. Coord. Chem. Rev. 2011, 255, 2303-2314. [CrossRef]

32. Buglyó, P.; Crans, D.C.; Nagy, E.M.; Lindo, R.L.; Yang, L.; Smee, J.J.; Jin, W.; Chi, L.-H.; Godzala, M.E.; Willsky, G.R. Aqueous chemistry of the vanadiumIII (VIII) and the VIII- dipicolinate systems and a comparison of the effect of three oxidation states of vanadium compounds on diabetic hyperglycemia in rats. Inorg. Chem. 2005, 44, 5416-5427. [CrossRef]

33. Yue, Z.; Xiaoda, Y.; Kui, W. Permeation of vanadium (III, IV, V)-dipicolinate complexes across MDCK cell monolayer and comparison with Caco-2 cells. Chin. Sci. Bull. 2005, 50, 1854-1859. [CrossRef]

34. Pranczk, J.; Jacewicz, D.; Wyrzykowski, D.; Wojtczak, A.; Tesmar, A.; Chmurzynski, L. Crystal structure, antioxidant properties and characteristics in aqueous solutions of the oxidovanadium(IV) complex [VO(IDA)phen] · 2H2O. Eur. J. Inorg. 2015, 2015, 3343-3349. [CrossRef]

35. Guan, T.S.; Hee, N.C.; Lai, T.F.; Khoon, L.E.; Mansor, S.M.; Balraj, P.; Chu, T.L.; Yamin, B.M.; Ng, S.W. Oxovanadium(IV) dipicolinate: Structure nucleolytic and anticancer property. Mod. Appl. Sci 2008, 2, 117. [CrossRef]

36. Pobłocki, K.; Drzeżdżon, J.; Kostrzewa, T.; Jacewicz, D. Coordination complexes as a new generation photosensitizer for photodynamic anticancer therapy. Int. J. Moc. Sci 2021, 22, 8052. [CrossRef]

37. Kirillov, A.M.; Shul'pin, G.B. Pyrazinecarboxylic acid and analogs: Highly efficient co-catalysts in the metal-complex-catalyzed oxidation of organic compounds. Coord. Chem. Rev. 2013, 257, 732-754. [CrossRef]

38. Gawdzik, B.; Drzeżdżon, J.; Siarhei, T.; Sikorski, A.; Malankowska, A.; Kowalczyk, P.; Jacewicz, D. Catalytic activity of new oxovanadium (IV) microclusters with 2-phenylpyridine in olefin oligomerization. Materials 2021, 14, 7670. [CrossRef]

39. Malinowski, J.; Jacewicz, D.; Gawdzik, B.; Drzeżdżon, J. New chromium (III)-based catalysts for ethylene oligomerization. Sci. Rep. 2020, 10, 16578. [CrossRef] [PubMed]

40. Bersted, B.H.; Belford, R.L.; Paul, I.C. Crystal and molecular structure of orthorhombic vanadyl(IV) pyridine-2, 6-dicarboxylate tetrahydrate. Inorg. Chem. 1968, 7, 1557-1562. [CrossRef]

41. Drzeżdżon, J.; Pawlak, M.; Matyka, N.; Sikorski, A.; Gawdzik, B.; Jacewicz, D. Relationship between Antioxidant Activity and Ligand Basicity in the Dipicolinate Series of Oxovanadium(IV) and Dioxovanadium(V) Complexes. Int. J. Mol. Sci. 2021, 22, 9886. [CrossRef] [PubMed]

42. Li, M.; Ding, W.; Smee, J.J.; Baruah, B.; Willsky, G.R.; Crans, D.C. Anti-diabetic effects of vanadium (III, IV, V)-chlorodipicolinate complexes in streptozotocin-induced diabetic rats. Biometals 2009, 22, 895-905. [CrossRef]

43. Iio, K.; Kobayashi, K.; Matsunaga, M. Radical polymerization of allyl alcohol and allyl acetate. Polym. Adv. Technol. 2007, 18, 953-958. [CrossRef]

44. Sawada, H.; Tanba, K.I.; Oue, M.; Kawase, T.; Mitani, M.; Minoshima, Y.; Nakajima, H.; Nishida, M.; Moriya, Y. Synthesis and properties of novel fluoroalkylated allyl alcohol oligomers. Polymer 1994, 35, 4028-4030. [CrossRef]

45. Britovsek, G.J.P.; Gibson, V.C.; Wass, D.F. The search for new-generation olefin polymerization catalysts: Life beyond metallocenes. Angew. Chem. Int. Ed. 1999, 38, 428-447. [CrossRef]

46. Drzeżdżon, J.; Chmurzyński, L.; Jacewicz, D. Geometric isomerism effect on catalytic activities of bis(oxalato) diaquochromates(III) for 2-chloroallyl alcohol oligomerization. J. Chem. Sci. 2018, 130, 116. [CrossRef]

47. Cossee, P. Ziegler-Natta catalysis I: Mechanism of polymerization of $\alpha$-olefins with Ziegler-Natta catalysts. J. Catal. 1964, 3, 80-88. [CrossRef]

48. Corradini, P.; Guerra, G.; Cavallo, L. Do new century catalysts unravel the mechanism of stereocontrol of old Ziegler-Natta catalysts? Acc. Chem. Res. 2004, 37, 231-241. [CrossRef]

49. Allegra, G. Discussion on the mechanism of polymerization of $\alpha$-olefins with Ziegler-Natta catalysts Macromol. Chem. Phys. 1971, 145, 235-246. [CrossRef] 